\title{
Funkcja przewodniczącego Rady Europejskiej - kompetencje formalne i nieformalne w świetle postanowień traktatu lizbońskiego i praktyki działań ${ }^{1}$
}

\section{Wprowadzenie}

Traktat z Lizbony przyniósł znaczące zmiany w strukturze instytucjonalnej Unii Europejskiej. Rada Europejska (RE) stała się pełnoprawną instytucją z własnym przewodniczącym. Wcześniej stanowisko to miało charakter nieformalny, ponieważ statut samej Rady Europejskiej nie był w pełni uregulowany, co znacząco wpływało na charakter jej działań. Do wejścia w życie tego traktatu Radzie Europejskiej przewodniczył szef państwa lub rządu państwa członkowskiego, które sprawowało rotacyjną prezydencję w Radzie Unii Europejskiej (UE). 10-11 grudnia 2009 roku, po raz ostatni, szczytowi Rady Europejskiej przewodniczył premier Szwecji, Fredrik Reinfeldt. Zmiany w formule funkcjonowania tej instytucji dokonały się pomimo działań państw członkowskich na rzecz ochrony swoich kompetencji decyzyjnych (Puetter, 2014). Tuż po wejściu w życie Traktatu UE stanęła przed szeregiem wyzwań. Turbulencje wewnętrzne na polu różnicy interesów i kryzysy zewnętrzne zbiegły się z procesem kreowania nowego ładu relacji międzyinstytucjonalnych. Funkcje aktorów instytucjonalnych, w szczególności przewodniczącego Rady Europejskiej, kształtowały się w obliczu narastającego kryzysu (Craig, 2011). Unia, po raz kolejny, przekształcała się w procesie konfliktu, napięcia i sporu o finanse. Państwa członkowskie obserwowały ten proces z narastającymi roszczeniami wobec osób, którym powierzono kompetencje, jednocześnie nie niwelując mechanizmów ograniczających ich większe zaangażowanie na rzecz zarządzania kryzysowego. Dodatkowo wydarzenia w południowym i wschodnim sąsiedztwie Unii Europejskiej sprawiły, że kwestie bezpieczeństwa zdominowały agendę polityczną po roku 2012 (Sus, 2019, s. 61-62). Od tego czasu, w konkluzjach Rady Europejskiej, głównym dominantem stały się walka z narastającymi problemami społeczno-gospodarczymi i konieczność zwiększenia aktywności Unii na arenie międzynarodowej w obliczu zagrożeń zewnętrznych.

Niniejszy artykuł skupia się na roli przewodniczącego Rady Europejskiej w ramach instytucjonalnych Unii Europejskiej, zgodnie z zapisami traktatu lizbońskiego. W tekście wskazano na rosnący wpływ tej instytucji, wykraczający poza sformułowania za-

${ }^{1}$ Artykuł został przygotowany w ramach projektu finansowanego przez Narodowe Centrum Nauki: „Rada Europejska w procesie kształtowania kompetencji formalnych i nieformalnych w zakresie działań zewnętrznych Unii Europejskiej”, nr 2015/19/B/HS5/00131. 
warte w traktacie z Lizbony, oraz na narastającą krytykę, którą stymuluje ta ewolucja. Dokonując przeglądu krytycznych punktów widzenia odnoszących się do roli, jaką sprawuje przewodniczący Rady Europejskiej, w tekście dokonano analizy czynników warunkujących zmiany formuly funkcjonowania tego urzędu. Przedstawione zostały istniejące struktury powiązań międzyinstytucjonalnych warunkujące pełnienie przez niego funkcji. W artykule oparto się na założeniu, iż dotychczasowa zasada korelacji zadań oparta na uzupełnianiu kompetencji uległa modyfikacji. Narastanie sytuacji kryzysowej wpłynęło na zaburzenie dotychczasowej równowagi instytucjonalnej, a jednocześnie zbiegło się z procesem zmian kompetencyjnych zainicjowanych zmianą traktatu w roku 2009. Artykuł składa się z dwóch części. W pierwszej pokazana jest specyfika urzędu przewodniczącego Rady Europejskiej i stan badań dotyczący roli tego stanowiska w procesie decyzyjnym w odniesieniu do zakresu jego kompetencji. W drugiej części zaproponowany jest zakres przyjętych ról w modelu sprawowania funkcji, który definiowany jest poprzez zmienne zależne i niezależne wpływające na kształt kompetencji Przewodniczącego Rady Europejskiej. Wnioski zawierają podsumowanie wartości eksploracyjnej, jaką wnoszą proponowane składowe do budowy modelu.

Zaproponowane $\mathrm{w}$ artykule podejście jest komplementarne wobec stosowanych koncepcji badawczych w badaniach procesu decyzyjnego w Unii Europejskiej. W ramach przyjętego spektrum analizy, na bazie wyselekcjonowanych studiów przypadku w okresie pełnienia funkcji przez dwóch przewodniczących Hermana Van Rompuya i Donalda Tuska, uznano za właściwe przyjąć technikę śledzenia procesu (Hall, 2013, s. 20-30; Ławniczak, 2018, s. 49-61). Umożliwia ona śledzenie mechanizmów przyczynowych wyjaśniających dany przypadek. Taka metoda umożliwiła wskazanie aktywności przewodniczących $\mathrm{w}$ ramach przedstawionej funkcji w określonym obszarze kompetencyjnym. Konieczna do przeprowadzenia śledzenia procesu była analiza dokumentów prawnych określających zakres zobowiązań traktatowych, jak i innych materiałów źródłowych dotyczących danego przypadku. Autorka korzystała z dorobku polskiej i zagranicznej literatury z zakresu integracji europejskiej. Bardzo duży wpływ na rozważania wywarły wywiady pogłębione $\mathrm{z}$ osobami z gabinetu pełniącego funkcję Przewodniczącego Rady Europejskiej Donalda Tuska przeprowadzone w latach 2017-2018. W tym okresie Autorka odbyła także rozmowy z pracownikami przedstawicielstw państw członkowskich przy UE (Polski, Niemiec, Czech), którzy chcieli pozostać anonimowi.

\section{Od rotacyjnego do stałego przewodnictwa Rady Europejskiej}

Formuła przewodniczenia obradom Rady Europejskiej funkcjonowała już u początków jej powstania. Wykształcił się zwyczaj rotacyjnego, półrocznego przewodnictwa zmieniającego się z dniem 1 stycznia i 1 lipca. Prowadzenie roli wiodącej w procesach kształtowania decyzji politycznej powierzono przywódcy państwa, które sprawowało przewodnictwo w Radzie UE. Uznano, iż Rada, jak i Rada Europejska powinny prowadzić politykę w tożsamym, wytyczonym przez Radę Europejską, kierunku (szerzej na temat badań związanych z ewolucją RE: Werts, 2008; Eggermont, 
2012; Schoutheete, 2006; Wessels, 2016; Pernice, 2004, s. 31-54). Wcześniejszy system był krytykowany jako niepozwalający prowadzić spójnej, długoterminowej polityki. Nie na wiele zdało się także ustalanie i wprowadzenie wspólnego programu działań trzech następujących po sobie prezydencji (Szczerba-Zawada, 2014). Zaproponowane nowe regulacje odnoszące się do funkcjonowania Rady Europejskiej, w tym zadania stałego przewodniczącego były częścią projektu systemowej reformy Unii Europejskiej, która miała w zamyśle stanowić odpowiedź na problem skuteczności działania unijnej struktury organizacyjnej (Doliwa-Klepacka, 2016, s. 118). Rozbieżności $\mathrm{w}$ interesach poszczególnych państw były na tyle silne, że nie pozwalało to na spójne wypracowywanie stanowisk negocjacyjnych przedkładanych na forum RE. Niektórzy badacze podkreślają także, że zmiany były odpowiedzią na kryzys przywództwa w Unii Europejskiej (Witkowska-Chrzczonowicz, 2014, s. 134). Czy, a jeżeli tak, w jakim celu szefowie rządów i państw potrzebowali przewodniczącego? Zdefiniowanie tej nowej postaci w RE wymagało określenia jego roli. Zakres funkcji szefa Rady Europejskiej budził kontrowersje zarówno podczas prac konwentu przygotowującego Traktat ustanawiający Konstytucję dla Europy, jak i konferencji międzyrządowej poprzedzającej przyjęcie traktatu lizbońskiego (Wojtowicz, 2004). Główne obawy wiązały się z realną władzą oddziaływania na proces stanowienia decyzji politycznej, którą miałaby otrzymać nowa postać na scenie europejskiej. Z jednej strony, przywódcy dużych państw nie chcieli mieć konkurenta politycznego, ograniczającego ich wpływ na proces integracji. Nie wszyscy liderzy państw członkowskich chcieli, aby nowa postać narzucała narrację w sprawach ważnych dla UE, kradnąc 'show' ogłaszania ich sukcesów. Z drugiej strony, małe państwa sądziły, że Przewodniczący będzie marionetką w rękach głównych liderów europejskich (Tallberg, 2008, s. 689). Biorąc pod uwagę głosy obu stron, już w założeniach przyświecających tworzeniu tego stanowiska władza Przewodniczącego miała zostać ograniczona poprzez podporządkowanie funkcjonalne, a także instytucjonalne. To pierwsze wiązało się przede wszystkim z określeniem jego zadań, ze wskazaniem na główną przypisaną mu rolę - koordynującego pracę Rady Europejskiej, inaczej rzecz ujmując administratora europejskiego. To drugie oznaczało, silne splecenie możliwości sprawowania jego funkcji w sieci interakcji z innymi instytucjami, w szczególności Komisją Europejską. Powiązania międzyrządowe i międzyinstytucjonalne stworzyły swoisty mechanizm współzależności, co w konsekwencji podporządkowało Przewodniczącego Rady Europejskiej, zarówno w sferze aktywności na scenie europejskiej, jak i jako reprezentanta zewnętrznego.

Zapis o procedurze wyboru przewodniczącego nie budził tak dużych sporów, ale kolejne próby wyłaniania kandydatów i próby ich zatwierdzenia pokazały jak trudne jest zastosowanie zapisów traktatowych w praktyce. Po zmianach lizbońskich, zgodnie z postanowieniami art. 15 ust. 5 TUE (Treaty..., 2009), Rada Europejska wybiera swojego stałego przewodniczącego większością kwalifikowaną na okres dwóch i pół roku. Jego mandat może być jednokrotnie odnawialny. Inne instytucje nie mają żadnych uprawnień w procedurze wyboru Przewodniczącego. Ta procedura stanowi odzwierciedlenie międzyrządowego, a nie wspólnotowego podejścia do integracji. Znacząco różni się ona od procedur wyłaniania innych przewodniczących głównych instytucji UE. Decyzja Rady Europejskiej w sprawie wyboru jej przewodniczącego 
podejmowana jest $\mathrm{w}$ głosowaniu, w którym biorą udział wyłącznie szefowie rządów lub państw Unii ${ }^{2}$. Pozostali członkowie Rady Europejskiej, w tym do tej pory pełniący obowiązki Przewodniczący Rady Europejskiej, nie uczestniczą w głosowaniu. We współczesnych naukach politycznych istnieje kilka niezbędnych wymagań dotyczących odpowiedzialnej władzy. Jednym z nim jest uznanie, iż osoby sprawujące ważne funkcje polityczne powinny być wybierane przez obywateli w drodze rywalizacji między programami politycznymi rywalizujących ze sobą kandydatów. Wynika to z faktu, iż sprawujący władzę wykonawczą odgrywają dominującą rolę przywództwa politycznego, ustalania agendy i reprezentacji zewnętrznej. Bez ograniczeń wynikających z regularnej walki o władzę nie byłoby gwarancji, że rząd będzie nadal zapewniał najlepszą politykę lub działał w sposób nieskorumpowany. W efekcie tylko wybory mogą zagwarantować zgodność preferencji wyborców z dzierżącymi władzę urzędniczą (Powell, 2000). Dyskusja na temat bezpośredniego wyboru Przewodniczącego powraca podobnie jak połączenie funkcji przewodniczącego KE i RE (Hix, 2002). Głównym niemieckim orędownikiem tej koncepcji był Wolfgang Schäuble, niemiecki minister spraw wewnętrznych. Takie rozwiązania proponowane przez polityków i teoretyków wydaje się jednak w bliższej perspektywie niemożliwe do zastosowania (Duff, 2010; Craig, 2005, s. 417-418). Z jednej strony mamy zatem wątpliwości, gdyż Przewodniczący nie ma mandatu demokratycznego do pełnienia funkcji, z drugiej strony silniejsza jest obawa, iż taki mandat da podstawę do nieoczekiwanych zmian systemowych. Jednym z potencjalnych scenariuszy byłoby przekształcenie prowadzące do tworzenia gabinetu rządowego na czele z wybieralnym Przewodniczącym. Legitymizacja z jednoczesnym wzmocnieniem jego prerogatyw miałaby bardzo duże znaczenie, nie tylko w postrzeganiu jego funkcji przez obywateli, ale także przez szefów państw i rządów. Demokratyczny mandat dla Przewodniczącego byłby sygnałem dla dalszego rozwoju podstaw systemu politycznego UE w formule międzyrządowej.

Zgodnie z podpisanym Paktem Stabilności, kadencje szefa Rady Europejskiej i szefa posiedzeń przywódców państw należących do strefy euro pokrywają się w czasie. Funkcji tych nie musi pełnić ta sama osoba. Jednakże przywódcy państw podjęli decyzję o wyborze Van Rompuy’a, jak i jego następców, do pełnienia obu funkcji.

\section{Kompetencje formalne i nieformalne}

Traktat z Lizbony i wprowadzone przez niego zmiany instytucjonalne zostały wielokrotnie opisane $\mathrm{w}$ literaturze przedmiotu $\mathrm{i} \mathrm{w}$ tym artykule nie zostanie dokonana szczegółowa analiza jego zapisów (m.in. Barcz, 2010; Węc, 2011, s. 193-210; Rewizorski, Przybylska-Maszner, 2013; Phinnemore, 2013; Ritleng, 2016; Hodson, Peterson, 2017). Na użytek poniższego opracowania wystarczy wskazać, iż kluczowym elementem w zakresie pozycji Przewodniczącego Rady Europejskiej było określenie jego zadań w art. 15 Traktatu o Unii Europejskiej (TUE). Osoba sprawująca tę funkcję ma przede wszystkim przewodniczyć szczytom Rady Europejskiej i kierować jej praca-

${ }^{2}$ Decyzja Rady Europejskiej podejmowana jest przy zastosowaniu zasad, określonych w artykule 16 ustęp 4 TUE i artykule 238 ustęp 2 TFUE. 
mi, czuwać nad przygotowaniami do szczytów Rady Europejskiej oraz nad ciągłością jej działań we współpracy z przewodniczącym Komisji oraz na podstawie wyników prac Rady do Spraw Ogólnych, przyczyniać się do spójności i konsensusu na forum Rady Europejskiej, a także przekazywać sprawozdanie Parlamentowi Europejskiemu po każdym spotkaniu Rady Europejskiej.

Z powyższego zapisu wynika zakres kompetencji Przewodniczącego, który ma charakter formalny, ale $\mathrm{z}$ biegiem lat praktyki pełnienia funkcji wypracowany został dodatkowy zakres kompetencji o charakterze nieformalnym. Wypracowanie dodatkowego katalogu wynika z utylitarnej konieczności zapewnienia prawidłowego funkcjonowania mechanizmów sprawczych pełnienia urzędu, ale też może oznaczać chęć rozszerzenia zakresu oddziaływania przez pełniącego urząd w celach wykraczających poza dotychczas określone zobowiązania. Kompetencje nieformalne mają na celu przynieść praktyczną korzyść, zarówno w sferze zarządzania instytucją, jak i zarządzania procesami międzyinstytucjonalnymi lub w procesie koordynacji stanowisk w ujęciu międzyrządowym. Z. Czachor twierdzi, iż do innych czynników kształtujących pozaformalny świat władzy instytucjonalnej zaliczyć można dysponowanie siłą autorytetu przez zorganizowanych decydentów politycznych (Czachór, 2013, s. 243).

Kompetencje wskazują na zakres uprawnień do podejmowania decyzji, jak i do realizacji określonych zadań (Stacey, Rittenberger, 2003, s. 858-883). Ich wykonanie jest często związane $\mathrm{z}$ określoną procedurą. $\mathrm{W}$ tym przypadku jej przestrzeganie przesądza o kompetentnym wykonaniu powierzonych zadań, bardzo często niezależnie od tego, czy osiągnięto zamierzony rezultat. Zakres tego pojęcia ulega zmianie. Wskazując na posiadanie kompetencji oznaczamy nie tylko posiadanie formalnych uprawnień w ramach znanych procedur, bądź nieformalnego przyzwolenia ich przypisania, lecz także, a często przede wszystkim praktyczną zdolność do realizacji zadań. Zdolność skutkuje prawidłowym wykonywaniem obowiązków związanych z pełnieniem funkcji, a także realizacją postawionych celów organizacji. Zachowanie wykonującego zadanie $\mathrm{w}$ ramach powierzonych kompetencji jest ściśle związane z przewidywaną efektywnością.

Znając wzorce zachowań możemy uznać prawidłowość wykonywania kompetencji. Porównanie umożliwia nam uznanie określonych zasad działania jako prowadzących do osiągnięcia celów. Dodatkowo, przyznanie kompetencji oznacza nadanie stopnia odpowiedzialności za przyjęcie i wykonanie zadania w określonym celu. Pojęcie kompetencji zakłada uwzględnianie sfery zmienności warunków realizacji zadań, w tym zwłaszcza możliwości dostosowania do nowych wyzwań, co w konsekwencji może prowadzić do zmiany standardów ich realizacji. Dla Przewodniczącego Rady Europejskiej obszar jego kompetencji oznacza nie tylko możliwość określenia zakresu wykonywanej pracy, to także powierzona mu odpowiedzialność za wykonanie zadań zgodnie z zasadami, przyjętymi standardami zachowań, ale z uwzględnieniem zmiennych warunków wymuszających na nim dostosowanie do okoliczności trybu pracy. Praktyka pełnienia obowiązków przez przewodniczących pokazuje, że bardzo często ich kompetencje wyrażały się poprzez akcentowanie samodzielności i własnego podejścia w realizacji zadania. To odniesienie nie stoi w opozycji do założenia, że podjęcie się pełnienia tego urzędu ściśle związane zostało z odpowiedzialnością za reali- 
zację pracy zgodnie z postanowieniami traktatowymi, ale nade wszystko z ustalonymi z przywódcami państw członkowskich standardami.

\section{Praktyka pełnienia funkcji Przewodniczącego Rady Europejskiej - urzędnik, komunikator, strateg, broker negocjacyjny, przywódca polityczny}

Przewodniczący Rady Europejskiej i jego najbliższe zaplecze to główni rozgrywający podczas spotkań Rady Europejskiej. To oni mają doprowadzić do uzgodnienia tekstu konkluzji i komunikować o jego treści opinii publicznej. Przewodniczący pełni rolę brokera prowadzącego negocjacje między zaangażowanymi stronami, proponując kompromisowe rozwiązania problemów, a w efekcie starając się zainicjować dającą się zaakceptować propozycję (Mintrom, 1997, s. 737; Minstrom, Norman, 2009, 649-667). Choć ma ograniczone zasoby (mały sztab wsparcia administracyjnego) Przewodniczący może generować pomysły i przekonywać państwa członkowskie do przygotowanego projektu. Do jego zadań należy: wypracowywanie kompromisu i zdobywanie poparcia dla pomysłów, za którymi stoi większość; budowanie koalicji państw członkowskich o podobnych poglądach; uwzględnianie różnorodnych preferencji państw członkowskich. W literaturze przedmiotu dominuje przekonanie o pasywnej roli przewodniczącego Rady Europejskiej. I. Tommel kwestionuje to, że Przewodniczący RE działa przede wszystkim jako neutralny broker, ale potwierdza, że swoimi działaniami przyczynił się do przyspieszenia integracji poza krajowymi preferencjami.

Organizacja samych spotkań i konsultacji je poprzedzających to skomplikowany proces, którego celem jest po pierwsze wypracowanie treści projektu konkluzji, a potem uzgodnienie ostatecznej wersji wyrażonego stanowiska państw. Głównymi aktorami tego spektaklu politycznego są zgromadzeni przywódcy. To co ważne, kryje się jednak za drzwiami obrad, to tam zgromadzeni są szerpowie i stali przedstawiciele, których zadaniem jest doradzanie, konsultowanie, ustalanie. To oni spotykają się, wykonują setki rozmów telefonicznych w celu wypracowania stanowisk negocjacyjnych co do kształtu decyzji politycznej. Ich praca przekłada się na sukces ich szefów. Warto zwrócić uwagę, że od traktatu lizbońskiego w spotkaniach nie uczestniczą już ministrowie, co mocno wpłynęło na organizację przepływu informacji i proces kreowania stanowisk podczas szczytu (Lewis, 2015). Na ostateczny kształt tekstu konkluzji wpływ ma dynamika rozmów obecnych na sali przywódców. To tam uwidacznia się emanacja napięcia sporów między państwami członkowskimi. To od talentu negocjacyjnego przywódców, ale także Przewodniczącego, zależy skala sukcesu (Janning, 2005, s. 821-833). Pamiętać należy, że każdy szczyt kończy się sukcesem, ale jego gradacja bywa różna. Co ważne, Przewodniczący Rady Europejskiej nie jest realizatorem konkluzji i nie angażuje się we wdrażanie przyjętych decyzji politycznych. Dokonując rozróżnienia między typami przywództwa, K. R. Wurzel przedstawia argument, iż Rada Europejska i Rada UE ma największe zdolności strukturalne i w zakresie zarządzania, a państwa członkowskie - najważniejsze zdolności poznawcze (Wurzel i in., 2019). P. Świeboda wskazuje, iż ,zakres odpowiedzialności stałego przewodniczącego oznacza, że mamy tutaj do czynienia z rzeczywistą funkcją polityczną, wykraczającą poza rolę gospodarza i moderatora dyskusji. Intencją traktatu z Lizbony 
było wyposażenie przewodniczącego Rady Europejskiej w kompetencje pozwalające na autentyczne kierowanie politycznym sztabem Unii Europejskiej. Z drugiej strony, Traktat zawiera gwarancje zachowania równowagi instytucjonalnej poprzez wymóg współpracy z Komisją Europejską oraz „,działanie na podstawie” prac Rady ds. Ogólnych" (Świeboda, Przewodniczacy..., 2012).

Z pewnością przewodniczący Rady Europejskiej mogą pretendować do bycia liderami politycznymi. Świadczy o tym ich zaangażowanie na rzecz opracowania własnych propozycji rozwiązań politycznych. Choć widać znaczące w tej kwestii różnice między pierwszym a drugim przewodniczącym. Herman Van Rompuy nie był postrzegany jako przywódca z własną wizją strategiczną, co mu sprzyjało przy wyborze, jak i nie szkodziło później w trakcie pełnienia funkcji, gdyż nie stanowił zagrożenia dla dotychczas wypracowanego ładu wypracowywania decyzji politycznej przez liderów największych unijnych państw (ocena kadencji tego Przewodniczącego: Przybylska-Maszner, 2012). Zarówno przed powołaniem, jak i po wyborze nie przedstawił spójnego programu uwzględniającego założenia związane z jego działaniami, a obejmującego okres trwania całej kadencji. Uznając się za moderatora, negocjatora, brokera przypisana mu została funkcja kolejnego urzędnika Unii Europejskiej. Kolejny Przewodniczący RE Donald Tusk wielokrotnie dał się poznać jako inicjator i kreator. Jego cechy i doświadczenie polityczne sprawiło, że wprowadzał nowe rozwiązania, często wykraczając poza formalne ramy dotyczące działań o charakterze politycznym. Przykładem tego może być przesyłanie listów do 27 przywódców państw, czy otwarcia spotkań (tzw. doorstep statement/doorstep remarks). Precyzyjna definicja przywództwa politycznego zapewne nie istnieje, ale warto zaznaczyć, iż w silnie zinstytucjonalizowanej organizacji, jaką jest UE, od początku jej powstania, istniało przywództwo instytucjonalne i przywództwo jednego lub grupy państwa (Metcalfe, 1998). W każdym z dwóch przypadków mieliśmy do czynienia z przywództwem, które wynikało nie tylko z zajmowanych funkcji, ale przede wszystkim z charakteru i charyzmy lidera politycznego. Przewodniczący RE, aby został uznany za przywódcę powinien inicjować rozwiązania, ale nade wszystko kreować wizje przyszłości i inspirować opinię publiczną. To co uniemożliwia, bądź ogranicza, Przewodniczącemu bycie realnym przywódcą politycznym to zdolność do wprowadzania w życie własnych rozwiązań. Primo, za jego sukcesem negocjacyjnym stoi 27 przywódców państw współkreujących to rozwiązanie. Secundo, charyzma, bez zdolności operacyjnych, nie wystarcza. Sprawne zarządzanie w Radzie Europejskiej sprowadza się do eurokracji w technokratycznym wydaniu. Ponadto, polityczna legitymacja do wzmocnienia pozycji skutecznego przywództwa UE jest ograniczona, gdyż UE jest zbudowana na idei, że przywództwo powinno być rozproszone na wielu poziomach w celu uniknięcia powtórzenia się w przyszłości wzorców z historii Europy. W europejskim myśleniu politycznym istnieje silne przekonanie, że władza i przywództwo muszą być ograniczane, bardziej zbliżone do heterarchii niż hierarchii (Tömmel, Verdun, 2017, s. 103-112). W związku z tym obowiązki powinny być dzielone i nakładane między różne instytucje. Uprawnienia do delegowania uprawnień różnią się w zależności od obszaru polityki i kwestii (Bäckstrand, Elgström, 2013, s. 1369-1371).

To co jest zauważalne od końca lat 80 . to przesunięcie centrum podejmowania decyzji politycznej z Komisji do Rady Europejskiej. Komisja, nawet podczas kadencji 
C. Junckera, nie angażowała się w dyskutowanie trudnych tematów, unikając kontrowersji szkodzących jej wizerunkowi. Jeżeli wypowiadała się w spornym temacie, działo się to raczej na sugestie Rady Europejskiej, a nie z własnej inicjatywy. Nie można uznać, iż Komisja stała się zapleczem administracyjno-wykonawczym Rady i Rady Europejskiej, jednakże pogłębiające się od końca lat 90. kryzysy wewnętrzne i zagrożenia zewnętrzne sprawiły, że centrum decyzji politycznych przesunęło się $\mathrm{w}$ stronę Rady Europejskiej. Jak zauważa P. Thaler znaczenie Rady Europejskiej wzrasta, gdyż w UE uwydatnia się potrzeba koordynacji i nadzoru międzyrządowego. Na przykładzie polityki energetycznej pokazuje, iż nowa formuła międzyrządowości sprawia, iż Rada Europejska kwestionuje klasyczną rolę Komisji Europejskiej w dziedzinie, która była zakorzeniona w jej kompetencjach. Jednocześnie widoczna jest wzmożona współpraca między tymi dwiema instytucjami, dzięki którym Komisja zachowała znaczny potencjał w zakresie inicjatyw politycznych (Thaler, 2016, s. 571-585). W akademickiej debacie na temat uprawnień relatywnych i oddziaływania instytucji, powszechne stało się sugerowanie, szczególnie w przypadku zwolenników „nowej międzyrządowości” (ang. new intergovernmentalism), że Komisja Europejska słabnie. Neil Nugent wskazuje, iż tylko pod pewnymi względami tak właśnie jest. W niektórych obszarach i tylko w ograniczonym stopniu zauważalna jest utrata uprawnień, a w wielu aspektach można stwierdzić wzmocnienie jej pozycji, co głównie wynika z nieformalnych zasobów, którymi dysponuje Komisja w wykonywaniu jej funkcji (Nugent, 2016).

Przewodniczący Rady Europejskiej korzysta z polizbońskiego transferu władzy ze strony Komisji do Rady Europejskiej. Przewodniczący Komisji ma ogromne zaplecze, wiedzę i ogromne doświadczenie, spojrzenie horyzontalne na omawiane problemy, władzę wykonawczą w obrębie szeroko określonych kompetencji, ale ma ograniczony prestiż w relacjach z przywódcami państw. Z funkcją Przewodniczącego Rady Europejskiej wiąże się prestiż, ale jego kompetencje i możliwości działania są bardzo ograniczone. Dwa przykłady ograniczenia roli przewodniczącego Komisji przez Przewodniczącego Rady Europejskiej to: praktyka reprezentacji podwójnej na szczytach z państwami trzecimi (podwójnie kosztowna); przejęcie pozycji lidera negocjacyjnego, „stratega” w sprawach kryzysu gospodarczego (rola przewodniczącego Komisji sprowadzała się do opracowania szczegółowych programów).

Choć Rada Europejska podejmuje decyzje całkowicie niezależne od stanowiska kreowanego przez inne instytucje, wielokroć jej zaangażowanie polityczne było odpowiedzią na wniosek Komisji, bądź wyrazem odniesienia do spraw omawianych na forum Parlamentu. W praktyce zdarzało się, że dokumenty strategiczne KE nie były wcześniej konsultowane z RE i przekazane jej przewodniczącemu (przypadek Białej Księgi Junckera). Podobnie treść listów Przewodniczącego RE D. Tuska nie była konsultowana przez Przewodniczącego KE. Ponadto, postanowienia Traktatu nie przeszkodziły Radzie Europejskiej i jej przewodniczącemu w nieformalnym ustalaniu programu/agendy spotkań w szczegółowy sposób, często powodując napięcia z Komisją. P. Bocquillon i M. Dobbels analizując trzy obszary - pakiet klimatyczny i energetyczny, reformę zarządzania gospodarczego i reformę Schengen, badając wzorce interakcji między dwiema instytucjami w ustalaniu programu legislacyjnego określili, że wzajemne relacje KE-RE można najlepiej zdefiniować w kategoriach ,konkurencyjnej współpracy" (Bocquillon, Dobbels, 2013). 
Istotnymi zapisami traktatu były te przyznające Przewodniczącemu Rady Europejskiej zadania w zakresie reprezentacji zewnętrznej. Przewodniczący reprezentuje Unię w zakresie Wspólnej Polityki Zagranicznej i Bezpieczeństwa oraz stanowiącej jej część Wspólnej Polityki Bezpieczeństwa i Obrony wraz z Wysokim Przedstawicielem Unii do spraw zagranicznych i polityki bezpieczeństwa, który ma wspomagać w realizacji tej polityki i zapewniać jej jednolitość, spójność i skuteczność. Na mocy traktatu z Lizbony nowo powołany Wysoki Przedstawiciel stał się dodatkowym podmiotem planującym i realizującym politykę zagraniczną w imieniu Rady Europejskiej (Por. Rüger, 2011, s. 201-234). Jednocześnie na arenie międzynarodowej ważnym aktorem pozostał przewodniczący Komisji Europejskiej (Closa, 2012, s. 135-137).

Powyższa regulacja pozostawia swobodę praktycznej interpretacji. Działanie „W zakresie właściwości” Przewodniczącego Rady Europejskiej może oznaczać obszar spraw objętych konkluzjami Rady Europejskiej (wymiar relacji zewnętrznych UE). Traktat lizboński nie określa jasnego podziału zadań i kompetencji pomiędzy Wysokim Przedstawicielem a Przewodniczącym Rady Europejskiej, przewodniczącym KE w obszarze polityki zagranicznej UE. Stały Przewodniczący ma zapewniać reprezentację zewnętrzną UE ,na swoim poziomie oraz w zakresie swojej właściwości”. Jednakże w porównaniu z Wysokim Przedstawicielem nie ma określonych szczegółowych kompetencji i obowiązków w tym zakresie. Pełni zatem funkcje o charakterze reprezentacyjnym. Możliwe jest wkraczanie w ramy tej funkcji przez Wysokiego Przedstawiciela, gdy nie odczyta on swojej funkcji w operacyjny sposób i będzie chciał pełnić rolę kolejnego przedstawiciela UE w stosunkach zewnętrznych. Maria G. Amadio Vicere, badając przypadek zaangażowania UE w Kosowie, potwierdziła znaczenie międzyrządowych forów koordynacji polityki i wspólnego podejmowania decyzji, w tym Rady Europejskiej i Rady do Spraw Zagranicznych. Uznała te instytucje i osoby pełniące funkcje ich przewodniczących za główne katalizatory integracji i rozwoju relacji zewnętrznych (Vicere, 2016).

Od 2009 roku zauważalne są spory kompetencyjne w sferze reprezentacji zewnętrznej. Do wielokrotnego rozstrzygnięcia pozostawała kwestia udziału poszczególnych przewodniczących UE (KE, RE, PE, WP) w szczytach Unii Europejskiej z państwami trzecimi. Przewodniczący Rady Europejskiej reprezentuje Unię na zewnątrz w sprawach dotyczących wspólnej polityki zagranicznej i bezpieczeństwa, bez uszczerbku dla uprawnień Wysokiego Przedstawiciela. Jednocześnie na szczytach międzynarodowych ustanowiona została dwugłowa reprezentacja - Przewodniczącego Rady Europejskiej z Przewodniczącym Komisji Europejskiej. Przewodniczący Rady Europejskiej - Przewodniczący Komisji Europejskiej - Wysoki Przedstawiciel, to między tymi trzema uczestnikami spotkań Rady Europejskiej, bez prawa do udziału w głosowaniach RE, rozdzielono role w zakresie kształtowania WPZiB i określania relacji bilateralnych i wielostronnych. W tym obszarze pozycja Wysokiego Przedstawiciela została wzmocniona w ujęciu wykonawczym, lecz kompetencje decyzyjne pozostały w rękach państw członkowskich, w ramach dwóch instytucji: Rady Europejskiej i Rady do Spraw Zagranicznych. W tej pierwszej zadanie koordynacji powierzono jej Przewodniczącemu. Przewodniczący tych dwóch instytucji ściśle współpracują z przewodniczącym Komisji Europejskiej. Choć rola Komisji z jej przewodniczącym została ograniczona, to biorąc pod uwagę dwugłową formułę reprezentacji na forum 
spraw zagranicznych, mechanizm koordynacji stanowisk jest kluczowy dla zapewnienia wzajemności w procesie konsultacji stanowiska wspólnego. O ile w relacji Przewodniczący KE - Wysoki Przedstawiciel mamy do czynienia z podporządkowaniem, o tyle w relacji przewodniczący RE i przewodniczący KE zauważamy relację konfrontacji lub wzajemnego uzupełniania. Wysoki Przedstawiciel stoi na czele Rady UE do spraw zagranicznych, która ściśle współpracuje z Radą Europejską i koordynującym jej prace przewodniczącym. Każda $\mathrm{z}$ tych postaci jest uzależniona od woli politycznej państw członkowskich w kreowaniu działań zewnętrznych UE.

W traktacie z Lizbony przewiduje się powiązania organizacyjne Rady Europejskiej z Komisją, gdyż jej przewodniczący jest członkiem Rady Europejskiej (bez prawa głosu), a Wysoki Przedstawiciel Unii do Spraw Zagranicznych i Polityki Bezpieczeństwa bierze udział w debatach Rady Europejskiej. Ponadto w ramach przygotowań do posiedzeń Rada Europejska często zwraca się do Komisji o przedłożenie sprawozdań, co wymusza dużą aktywność międzyinstytucjonalną Przewodniczącego RE (Waele, Broeksteeg, 2012, s. 1039-1074). W praktyce mamy do czynienia z dwoma liderami, dwoma ośrodkami władzy, dwoma centrami decyzyjnymi, kreującymi strategię rozwoju Unii. Choć dzieli je bardzo mała odległość ronda Schumana, to rozbieżności polityczne między nimi stanowią wielokroć polityczną przepaść nie do pokonania.

Warte zaznaczenia są trudności w efektywnym wdrożeniu stanowiska Przewodniczącego Rady Europejskiej w związku z mieszanym systemem Prezydencji przyjętym w traktacie (Przybylska-Maszner, 2011, s. 187-192). Jest to rozwiązanie kompromisowe, łączące elementy przewodnictwa stałego w Radzie Europejskiej i Radzie ds. Zagranicznych i rotacyjnego w pozostałych składach Rady. Efektywność systemu jest pochodną dobrej współpracy między stałym Przewodniczącym a prezydencją sprawowaną kolejno przez państwa członkowskie.

Artykuł 15 ust. 6 TUE przewiduje także obowiązek dla Przewodniczącego Rady Europejskiej przedstawiania Parlamentowi sprawozdania z każdego spotkania. Przewodniczący Rady Europejskiej spotyka się także co miesiąc z przewodniczącym Parlamentu oraz liderami grup politycznych. Dodatkowo, od początku roku 2011 wprowadzono nową nieformalną praktykę - odpowiadanie na przedstawiane przez posłów do PE pytania pisemne dotyczące jego działań politycznych. Parlament może również w sposób nieformalny wywierać wpływ na decyzje dzięki obecności przewodniczącego PE na posiedzeniach Rady Europejskiej oraz na spotkaniach partyjnych liderów europejskich frakcji politycznych odbywających się przed szczytami Rady Europejskiej, a także dzięki rezolucjom PE w sprawie punktów porządku obrad Rady Europejskiej, wyników posiedzeń oraz formalnych sprawozdań składanych przez Radę Europejską.

Przewodniczący jest także „medialną twarzą” instytucji, postacią rozpoznawalną kojarzoną powszechnie jako reprezentant UE. To on komunikuje o jej przedsięwzięciach, a pośrednio ma ogromny wpływ na budowanie marki instytucji w relacjach z obywatelami, a także innymi podmiotami na arenie międzynarodowej. Choć w zakresie jego zadań nie ma prowadzenia rozmów/konsultacji z różnymi partnerami w celu omówienia propozycji politycznych, to również on jest elementem sieci kontaktów i wpływów politycznego oddziaływania. Podobnie jak inne instytucje, Rada Europejska na czele z rozpoznawalnym Przewodniczącym buduje własne ramy polityki informacyjnej, której ważnym elementem jest kontakt za pomocą mediów z opinią publiczną. 
O możliwości wykonywania kompetencji decydują czynniki personalne, a także postawa, którą kreuje Przewodniczący w relacjach z innymi przedstawicielami instytucji. Na jego zachowanie ogromny wpływ ma wcześniej zdobyte doświadczenie zawodowe, a także wiedza proceduralna i posiadanie umiejętności dostrzegania i skutecznego wykorzystywania zależności międzyinstytucjonalnych. Przewodniczący Rady Europejskiej nie może sprawować żadnej krajowej funkcji publicznej. Warto podkreślić, że za jego sukcesem w wypełnianiu funkcji stoi jego zespół. Odpowiedni dobór osób może znacząco wspomóc w wykonywaniu kompetencji. W pracy wspiera go zaplecze administracyjne skupione w ramach biura, w którym zatrudnionych jest około 30 osób $^{3}$.

Jednym z celów niniejszego artykułu było przedstawienie zarysu konstrukcji podstaw modelu, który umożliwi analizę roli, jaką Przewodniczący Rady Europejskiej odgrywa w procesie kształtowania decyzji politycznej w UE. Szereg Autorów badało założenia koncepcji ról różnych aktorów zaangażowanych w kształtowanie procesu politycznego (m.in. Aggestam, 2006, s. 11-29; Bretherton, Vogler, 2005; Breuning 2011; Cantir, Kaarbo, 2012). Odwołując się do tych wyników badań zaprezentowano elementy będące podstawą do budowy modelu sprawowania funkcji przez Przewodniczącego RE. Kluczowa do oceny roli była analiza dokumentów pozwalająca na określenie zarysu sprawowanych funkcji, jak i praktyka pełnienia obowiązków. Punktem wyjścia do rozważań było pytanie - jakie role sprawuje przewodniczący Rady Europejskiej w obrębie sprawowanych kompetencji? Poniższa tabela zawiera zbiorcze przedstawienie przypisanych ról z odniesieniem do zakresu powierzonych zadań.

Tabela 1

Przewodniczący Rady Europejskiej - zakres zadań i przypisane role

\begin{tabular}{||l|l||}
\hline $\begin{array}{c}\text { Przypisana } \\
\text { rola }\end{array}$ & \multicolumn{1}{c||}{ Zakres zadań } \\
\hline 1 & \multicolumn{1}{|c||}{2} \\
\hline $\begin{array}{l}\text { Urzędnik } \\
\text { koordynator }\end{array}$ & $\begin{array}{l}\text { rola administracyjna, } \\
-\begin{array}{l}\text { wypełnianie powierzonych zadań przez liderów państw członkowskich w ramach } \\
\text { określonego mandatu, } \\
-\end{array} \\
- \text { zwoływanie spotkań, } \\
\text { ustalanie agendy spotkań. }\end{array}$ \\
\hline $\begin{array}{l}\text { Broker } \\
\text { negocjacyjny }\end{array}$ & $\begin{array}{l}\text { negocjowanie w celu wypracowania kompromisowego rozwiązania, } \\
\text { zdobywanie politycznego wsparcia dla przedstawionych pomysłów poprzez zjedny- } \\
\text { wanie grup państw członkowskich. }\end{array}$ \\
\hline
\end{tabular}

${ }^{3}$ Wysokość wynagrodzenia i dodatków związanych z wykonywaniem funkcji Przewodniczącego Rady Europejskiej ustalono podczas negocjacji budżetu Unii na rok 2009, w kwietniu 2008. Wysokość wynagrodzenia przewodniczącego jest równa wynagrodzeniu przewodniczącego Komisji Europejskiej. Kwestia wynagrodzenia Przewodniczącego miała znaczenie symboliczne. Biorąc pod uwagę zasadę ,ten kto zarabia najwięcej sprawuje najważniejszą funkcję” ustalono tożsame uposażenie Przewodniczącego RE w porównaniu do Przewodniczącego KE. Jego pensja to $138 \%$ najwyższej pensji funkcjonariusza publicznego UE, co wynosi około 25 tysięcy euro miesięcznie. Szczegółowe warunki jego zatrudnienia określono w odrębnej decyzji Rady, Por. Decyzja Rady z dnia 1 grudnia 2009 r. ustanawiająca warunki zatrudnienia Przewodniczącego Rady Europejskiej (2009/909/EU), Dz. U. UE L 322/35, 9.12.2009. 


\begin{tabular}{|c|c|}
\hline 1 & -2 \\
\hline $\begin{array}{l}\text { Rozgrywają- } \\
\text { cy strateg }\end{array}$ & $\begin{array}{l}\text { - } \text { aktywna moderacja, } \\
\text { - } \text { identyfikowanie problemów politycznych i skupianie na nich uwagi, } \\
\text { - } \text { inicjowanie rozmów na rzecz wybranych, zaproponowanych przez grupy państw } \\
\text { członkowskich, rozwiązań politycznych, } \\
\text { - } \text { przedstawianie propozycji zastosowania nowych (wypadkowych z kilku propozycji) } \\
\text { instrumentów reakcji na rzecz uzyskania konsensusu, } \\
\text { - } \\
\text { skuteczna mediacja między państwami członkowskimi w oparciu o możliwie najwyż- } \\
\text { szy do uzyskania wspólny mianownik zbieżności interesów, } \\
\text { - } \text { zaangażowanie w proces kształtowania decyzji politycznej, na rzecz znalezienia } \\
\text { wspólnego rozwiązania, } \\
\text { - } \\
\text { kooperacja z przedstawicielami pozostałych instytucji UE - współkompetencyjność. }\end{array}$ \\
\hline $\begin{array}{l}\text { Kreator } \\
\text { decyzji } \\
\text { politycznych }\end{array}$ & $\begin{array}{l}\text { - zaangażowanie na wszystkich etapach procesu kształtowania decyzji politycznej, } \\
\text { - } \text { zdobywanie wsparcia dla przedstawionych własnych pomysłów, tworzenie ostatecz- } \\
\text { nego kształtu konkluzji na spotkaniach RE. }\end{array}$ \\
\hline $\begin{array}{l}\text { Komunika- } \\
\text { tor }\end{array}$ & $\begin{array}{l}\text { - jako będący rozpoznawalną postacią - reprezentantem instytucji (jej „medialną twa- } \\
\text { rzą"), komunikującym o jej przedsięwzięciach, buduje markę instytucji w relacjach } \\
\text { z obywatelami, a także innymi podmiotami na arenie międzynarodowej, } \\
\text { - } \text { kontakt za pomocą mediów z opinią publiczną, } \\
\text { - prowadzenie rozmów/konsultacji z różnymi partnerami w celu omówienia propozycji } \\
\text { politycznych. }\end{array}$ \\
\hline $\begin{array}{l}\text { Lider/ } \\
\text { przywódca } \\
\text { polityczny }\end{array}$ & $\begin{array}{l}\text { - tworzenie szerokiego zaplecza politycznego dla kreowania własnej politycznej stra- } \\
\text { tegii, } \\
\text { - przewodzenie w ujęciu behawioralnym, wtedy gdy przywódcą politycznym jest ta } \\
\text { osoba, która ma największy wpływ na decyzje podejmowane przez grupę, a nie pozy- } \\
\text { cyjnym, gdy przywódca stoi na czele grupy dążącej do realizacji celów politycznych. }\end{array}$ \\
\hline
\end{tabular}

Źródło: Opracowanie własne.

\section{Podsumowanie}

Ustanowienie stałego Przewodniczącego Rady Europejskiej stało się jednym z wyzwań instytucjonalnych, które przyniósł traktat lizboński. Jego zadaniem stało się zapewnienie przygotowania i ciągłości prac Rady Europejskiej, we współpracy z Przewodniczącym Komisji i na podstawie prac Rady do Spraw Ogólnych, która przygotowuje posiedzenia. Zakres jego obowiązków w zakresie budowy powiązań międzyinstytucjonalnych i międzyrządowych jest jednak dużo szerszy. Przewodniczący ustanawia ramy ścisłej współpracy z szefami rządów i państw członkowskich, ich przedstawicielami, Prezydencją Rady, Przewodniczącym Komisji Europejskiej, a w zakresie swojej właściwości reprezentuje Unię na zewnątrz, bez uszczerbku dla uprawnień Wysokiego Przedstawiciela Unii do spraw zagranicznych i polityki bezpieczeństwa. Ciąży również na nim zobowiązanie do sprawozdań przed Parlamentem. Podsumowując można stwierdzić, iż po traktacie lizbońskim Przewodniczący Rady Europejskiej pełni funkcje zarówno administracyjną, jak i polityczną. W zakresie zadań administracyjnych możemy określić zadania typowo koordynacyjne i operacyjne w wymiarze międzyinstytucjonalnym i międzyrządowym. W zakresie zadań politycznych kluczowe stają się jego funkcje: reprezentacyjna i negocjacyjna.

Obserwując kadencje dotychczas pełniących obowiązki Przewodniczącego Rady Europejskiej zauważyć można było niejednoznaczności w interpretacji przepisów 
traktatu dotyczących podziału kompetencji między nim a Przewodniczącym Komisji Europejskiej, w mniejszym stopniu z Wysokim Przedstawicielem. Niepewność co do zastosowania treści traktatu sprawiła, że charakter nowopowstałej funkcji ścierał się w praktyce z ugruntowaną pozycją pełniącego obowiązki i mającego duże doświadczenie Przewodniczącego Komisji Europejskiej.

Przewodniczącym pełniącym ten urząd do roku 2019 nie brak było determinacji do nadawania politycznych impulsów pracom UE w celu realizacji bieżącej, kryzysowej agendy politycznej. Uznać ich trzeba za sprawnych urzędników wspomagających członków RE w wypracowaniu kompromisów, a jednocześnie pośrednio kreatorów rozwiązań, współodpowiedzialnych za projekt europejski. Główną barierą $\mathrm{w}$ ich pracy był niewielki gabinet, ograniczony liczebnie personel, małe zaplecze wspomagające pracę. Ich działania opierały się głównie na wsparciu służb Sekretariatu Generalnego Rady UE, które są odpowiedzialne np. za współpracę z prezydencją w sprawach związanych z konkluzjami Rady Europejskiej. Sukcesem dwóch Przewodniczący było zapewnienie ciągłości prac Rady Europejskiej, co wymuszało konieczność efektywnego systemu komunikacji z Komisją Europejską oraz państwami sprawującymi prezydencję oraz sprawne komunikowanie o decyzjach politycznych opinii publicznej.

Przewodniczący RE zdają sobie sprawę, że zakres ich kompetencji jest ograniczony, ale ich wypracowana praktyka współpracy międzyinstytucjonalnej wpływa na charakter wykonywania funkcji przez nich i i ich następców. Praktyka konkretyzuje szczegóły wykonywania funkcji i wpływa na zakres kompetencji nieformalnych. Droga do uzyskania kompetencji nieformalnych przesądza o wyborze potrzebnych i wykorzystywanych umiejętności personalnych. O potrzebnych umiejętnościach decyduje opis stanowiska określony w Traktacie, natomiast o sukcesie pełnienia funkcji przesądza konfrontacja kwalifikacji do pełnienia obowiązków z powierzonymi zadaniami. Istotne jest podkreślenie, że trudności i rozbieżności w wykonywaniu zadań mogą wystąpić w kilku obszarach: technicznej, interpersonalnej i kreatywno-koncepcyjnej. W każdej z tych sfer inaczej układają się relacje kwalifikacji do kompetencji. Ogromne znaczenie ma charyzma polityczna osób sprawujących funkcję.

Powyższy artykuł proponuje składowe do budowy modelu, który może zostać zastosowany do badania roli przewodniczącego Rady Europejskiej w procesie decyzyjnym. Dwie kadencje pełniących obowiązki Hermana Van Rompuya oraz Donalda Tuska pozwalają na przeprowadzenie szczegółowych analiz, wskazujących na wpływ tego aktora w układzie instytucjonalnym. W założeniu stanowisko to miało poprawić koordynację działań RE i przyczynić się do zwiększenia jej spójności. Badacze analizujący dynamikę postlizbońskiego procesu decyzyjnego, wskazywali na fakt pozostawania kompetencji decyzyjnych w rękach państw członkowskich i na sprowadzenie funkcji przewodniczącego RE do roli ograniczonego agenta. Ta obserwacja stanowiła punkt wyjścia do stworzenia modelu wskazującego na powiązania międzyinstytucjonalne. Może on zostać jeszcze rozbudowany w odniesieniu do działań przewodniczącego w relacji z państwami członkowskimi. Proponowane składowe modelu umożliwiają także uwzględnienie innych czynników wpływających na działania Przewodniczącego Rady Europejskiej, między innymi mechanizmów kontroli i nadzoru. 


\section{Bibliografia}

Aggestam L. (2006), Role theory and European foreign policy: a framework of analysis, w: The European Union's Roles in International Politics, red. O. Elgström, M. Smith, London-New York.

Barcz J. (2010), Unia Europejska na rozstajach. Traktat z Lizbony. Dynamika i główne kierunki reformy ustrojowej, Warszawa.

Bäckstrand K., Elgström O. (2013), The EU's Role in Climate Change Negotiations: From Leader to 'Leadiator", "Journal of European Public Policy", vol. 20, no. 10.

Bocquillon P., Dobbels M. (2014), An elephant on the 13th floor of the Berlaymont? European Council and Commission relations in legislative agenda setting, "Journal of European Public Policy", vol. 21, issue 1.

Bretherton C., Vogler J. (2006), The European Union as Global Actor, Routledge, London.

Breuning M. (2011), Role theory research in international relations: state of the art and the blind spots', w: Role Theory in International Relations: Approaches and Analyses, red. S. Harnisch, C. Frank, H. W. Maull, Routledge, London.

Cantir C., Kaarbo J. (2012), Contested Roles and Domestic Politics: Reflections on Role Theory in Foreign Policy Analysis and IR Theory, "Foreign Policy Analysis", vol. 8, no. 1.

Closa C. (2012), Institutional Innovation in the EU: The 'Permanent' Presidency of the European Council, w: The EU's Lisbon Treaty. Institutional Choices and Implementation, red. F. Laursen, Farnham.

Craig P. (2011), Institutions, Power and Institutional Balance, "Legal Research Paper Series", 48, University of Oxford., August.

Craig P. (2005), European governance: Executive andadministrative powers under the newconstitutional settlement, „International Journal of Constitutional Law” 3(2-3), June.

Czachór Z. (2013), Kryzys i zaburzona dynamika Unii Europejskiej, Elipsa.

Decyzja Rady Europejskiej z dnia 1 grudnia 2009 w sprawie wyboru Przewodniczącego Rady Europejskiej, 2009/879/UE, Dz. U. UE L 315 z dnia 2 grudnia 2019, s. 48.

Decyzja Rady z dnia 1 grudnia 2009 r. ustanawiająca warunki zatrudnienia Przewodniczącego Rady Europejskiej (2009/909/EU), Dz. U. UE L 322/35, 9.12.2009.

Doliwa-Klepacka A. (2016), Przewodniczacy Rady Europejskiej - od rotacji do wyborów, „Białostockie Studia Prawnicze", styczeń.

Duff A. (2010), Who is Herman Van Rompuy?, „FT.com”, 23 février, http://andrewduff.eu/en/article/2010/042378/who-is-herman-van-rompuy (1.05.2019).

Eggermont F. (2012), The Changing Role of the European Council in the Institutional Framework of the European Union. Consequences for the European Integration Process, Cambridge-Antwerp-Portland.

Hall P. (2013), Tracing the Progress of Process Tracing, "European Political Science", vol. 12, s. 20-30.

Hix S. (2002), Why the EU Should Have a Single President, and How She Should be Elected, Paper for the Working Group on Democracy in the EU for the UK Cabinet Office, Oct., https:// personal.lse.ac.uk/hix/Working_Papers/Why $\% 20$ the $\% 20$ EU\%20Should $\% 20 H a v e \% 20 a \% 20$ Single\%20President.pdf.

Hodson D. (2017), Institutions of the European Union, Oxford University Press.

Jańczak J. (2018), The European Council and the European Union's external activities. Forming relations with eastern neighbors, „Przegląd Politologiczny”.

Janning J. (2005), Leadership coalitions and change: the role of states in the European Union, "International Affairs", 81 (4), s. 821-833.

Lewis J. (2015), The Council of the European Union and the Council, w: Routledge Hanbook of European Politics, red. J. M. Magone, London-New York. 
Ławniczak K. (2018), Śledzenie procesu w badaniach politologicznych. Warianty i potencjal zastosowania, „Przegląd Politologiczny”, vol. 1, s. 49-61.

Metcalfe D. (1998), Leadership in European Union negociations: the Presidency of the Council, "International Negociation", nr 3, s. 413-434.

Mintrom M. (1997), Policy Entrepreneurs and the Diffusion of Innovation, "American Journal of Political Science", vol. 41, nr 3, s. 738-770.

Mintrom M., Norman P. (2009), Policy Entrepreneurship and Policy Change, "Policy Studies Journal", vol. 37, nr 4, s. 649-667.

Nugent N., Rhinard M. (2016), Is the European Commission Really in Decline?, "Journal of Common Market Studies", vol. 54, issue 5, September.

Pernice I. (2004), Democratic Leadership in Europe. The European Council and the President of the Union, w: The Government of Europe: Which Institution Design for the European Union, red. J. M. Beneuyto Pérez, I. Pernice, Baden-Baden.

Phinnemore D. (2013), The Treaty of Lisbon. Origins and Negotiation, Palgrave Macmillan.

Powell G. Bingham (2000), Elections as Instruments of Democracy, Yale University Press.

Przybylska-Maszner B. (2011), Polska prezydencja w obszarze Wspólnej Polityki Bezpieczeństwa i Obrony. Uwarunkowania. Mechanizm działania, założenia, w: Priorytety polskiego przewodnictwa w Radzie Unii Europejskiej, red. Z. Czachór, T. Szymczyński, Wydawnictwo Naukowe PWN, Warszawa.

Przybylska-Maszner B. (2012), Przewodniczacy Rady Europejskiej między strategia polityczna a rutyna pracy urzędnika, „Rocznik Integracji Europejskiej”, nr 6.

Puetter U. (2014), The European Council and the Council: new intergovernmentalism and institutional change, Oxford University Press.

Rewizorski M., Przybylska-Maszner B. (2013), System instytucjonalny Unii Europejskiej po traktacie z Lizbony. Aspekty polityczne i prawne, Warszawa.

Rüger C. (2011), A Position under Construction: Future Prospects of the High Representative after the Treaty of Lisbon, w: The High Representative for the EU Foreign and Security Policy - Review and Prospects, red. G. Müller-Brandeck-Bocquet, C. Rüger, Nomos.

Ritleng D. (2016), Independence and Legitimacy in the Institutional System of the European Union, Oxford University Press.

Schoutheete Ph. de (2006), The European Council, in: The Institutions of the European Union, red. J. Peterson, M. Shackleton, Oxford.

Sus M. (2019), Wysoki Przedstawiciel Unii Europejskiej do spraw zagranicznych i polityki bezpieczeństwa jako przedsiębiorca polityczny. Propozycja podejścia badawczego, „Rocznik Integracji Europejskiej", nr 13.

Stacey J., Rittberger B. (2003), Dynamic of formal and informal institutional change in the EU, "Journal of European Public Policy" 10(6), s. 858-883.

Szczerba-Zawada A. (2014), Przewodniczacy Rady Europejskiej, czyli o postlizbońskiej formule przewodnictwa w Radzie Europejskiej, „Przegląd Sejmowy”, nr 4(123).

Świeboda P., Przewodniczacy Rady Europejskiej - polityk czy urzędnik?, http://ec.europa.eu/polska/ news/opinie/080627_pl.htm, 1.05.2012.

Tallberg J. (2008), Bargaining Power in the European Council, "Journal of Common Market Studies", vol. 46. no. 3.

Thaler P. (2016), The European Commission and the European Council: Coordinated Agenda setting in European energy policy, „Journal of European Integration”, vol. 38.

Tömmel I. (2017), The standing president of the European Council: intergovernmental or supranational leadership?, "Journal of European Integration", vol. 39, issue 2. 
Tömmel I., Verdun A. (2017), Political Leadership in the European Union: An Introduction, "Journal of European Integration", vol. 39, no. 2.

Treaty of Lisbon amending the Treaty on European Union and the Treaty establishing the European Community, signed at Lisbon, 13 December 2007 Official Journal of the European Union, 2007.

Węc J. J. (2011), Reforma Wspolnej Polityki Zagranicznej i Bezpieczenstwa Unii Europejskiej w traktacie lizbonskim, „Politeja”, vol. 15, s. 193-210.

Werts J. (2008), The European Council, London.

Wessels W. (2016), The European Council, London-New York.

Witkowska-Chrzczonowicz K. M. (2014), Dynamika rozwoju Rady Europejskiej w systemie instytucjonalnym Unii Europejskiej, Torun.

Wojtowicz K. (2004), Projekt Traktatu ustanawiajacego Konstytucję dla Europy - podstawy ustroju i porządku prawnego Unii Europejskiej, „Przegląd Sejmowy”, nr 2.

Waele H. de, Broeksteeg H. (2012), The Semi-Permanent European Council Presidency: Some Relections on the Law and Early Practice, "Common Market Law Review", vol. 49.

Wurzel R. K., Liefferink D., Lullo Di M. (2019), The European Council, the Council and the Member States: changing environmental leadership dynamics in the European Union, "Enviromental Politics", vol. 28.

Vicere M. G. A. (2016), The roles of the President of the European Council and the High Representative in leading EU foreign policy on Kosovo, "Journal of European Integration", vol. 38, issue 5 .

\section{Streszczenie}

Artykuł skupia się na roli Rady Europejskiej w ramach instytucjonalnych Unii Europejskiej, zgodnie z zapisami traktatu lizbońskiego. W tekście wskazano na jej rosnący wpływ, wykraczający poza sformułowania zawarte w Traktacie, oraz na narastającą krytykę, którą stymuluje ta ewolucja. Dokonując przeglądu krytycznych punktów widzenia odnoszących się do roli, jaką sprawuje, w tekście dokonano analizy czynników warunkujących zmiany formuły funkcjonowania urzędu przewodniczącego Rady Europejskiej. Przedstawione zostały istniejące struktury powiązań międzyinstytucjonalnych warunkujące pełnienie przez niego funkcji. W artykule oparto się na założeniu, iż dotychczasowa zasada korelacji zadań oparta na uzupełnianiu kompetencji uległa modyfikacji. Narastanie sytuacji kryzysowej wpłynęło na zaburzenie dotychczasowej równowagi instytucjonalnej, a jednocześnie zbiegło się z procesem zmian kompetencyjnych.

Słowa kluczowe: Unia Europejska, Rada Europejska, system instytucjonalny UE, traktat lizboński

\section{The role of the President of the Europan Council - formal and informal competences in the light of the provisions of the Treaty of Lisbon}

\section{Summary}

The article deals with the role of the president of the European Council in the institutional framework of the European Union, as it has been laid down by the Lisbon Treaty. The text indicates its growing influence, beyond the wording of the Treaty, and the growing criticism that 
this evolution has stimulated. Reviewing the critical points of view relating to his role, the text analyzes the factors that determine changes in the formula for the functioning of the office of the President of the European Council. The existing structures of inter-institutional links that condition the performance of his function were presented. The article is based on the assumption that the current principle of correlation of tasks based on complementing competences has been modified. The worsening of the crisis situation disturbed the existing institutional balance, and at the same time coincided with the process of competence changes. The discussion also considers the proposal of reform of the institutional architecture of the EU.

Key words: European Union, European Council, EU institutional system, Treaty of Lisbon 
